Novruzova Nuriyyah Zakir qizi, Doctoral student, Azerbaijan Cooperation University

ORCID ID: 0000-0003-0668-5293

DOI: $10.32702 / 2306-6806.2021 .11 .116$

\title{
THE ROLE OF FINANCIAL MANAGEMENT AND QUESTIONS OF DEVELOPMENT OF ITS MECHANISMS IN THE MODERN PERIOD
}

Новрузова Нурія Закир кизи,

докторант, Азербайджанський Університет Кооперації

\author{
РОАЬ ФІНАНСОВОГО УПРАВАІННЯ ТА ПИТАННЯ РОЗВИТКУ ЙОГО МЕХАНІЗМІВ У \\ СУЧАСНОМУ ПЕРIOAI
}

The topic of financial control over business activities is discussed in this article. The author focuses on financial management methods in the modern context, the use of information technology to improve the control system, auditing, and challenges with electronic auditing, and other topics. Strengthening control over the use of budget funds, increasing tax system transparency, continuing changes to improve tax culture, bolstering positive trends in the country's Chamber of Accounts'activities, simplifying budget classification, and raising public awareness will all help improve the efficiency of financial control mechanisms and reduce corruption risks, according to the article.

Azerbaijan's current economic scenario is marked by frequent changes in the external and internal environments of businesses. Many businesses are compelled to operate under a shortage of credit resources, discrepancies in domestic regulation, and other factors. As a result, a priority factor in the formation of their competitiveness is effective financial decision-making in financial management, including effective financial decision-making, financial resource distribution and redistribution, and cash flow of the corporation, which should be based on comprehensive control, ensuring the targeted nature of distribution and a certain rate of return on invested capital.

Financial management and control systems based on outdated accounting and analysis methods, as well as planned and factor analysis, make it impossible to produce reliable results. Modern circumstances necessitate a qualitative shift in financial control as a foundation for ensuring the implementation of the levers of the corporation's financial management mechanism, including forecast indicators and the attainment of the corporation's strategic goals and objectives. Internal financial control is a critical component of the financial management system for making and implementing successful management decisions. It must be implemented at all levels of management to ensure high-quality management outcomes. Internal corporate financial control aims to adjust the corporation's production and management systems to the changing external environment, achieving target financial performance indicators, and maintaining the corporation's financial position in industrial markets. As a result, a successful firm must have a well-established financial management system, which is a guarantee of a company's success in a competitive environment.

The paper concludes with generalized findings about the subject under consideration.

У Статті розглядаються питання щодо фінансового контролю діяльності підприємств. Серед досліАжених аспектів автор приділяе особливу увагу механізмам фінансового управління за сучасних умов, інформаційні технології у вАосконаленні Системи контролю, аудит, питання застосування електронного аудиту тощо. У статті наголошується, що посилення контролю за використанням бюджетних коштів, підвищення прозорості податкової системи, продовження змін щодо підвищення податкової кУльтУри, посилення позитивнх тенденцій у діяльнсті Рахункової палати країни, спрощення бюджетної кАасифікації, а також підвищення обізнаності громадськості допоможуть підвищити ефективність механізмів фінансового контролю та зниження корупційних ризиків.

Поточна економічна ситуація в Азербайджані характеризується постійними змінами зовнішнього та внутрішнього середовища підприемств. Багато підприємств змушені працювати за умов нестачі доступних кредитних ресурсів, невідповідностей у внутрішньому законодавстві тощо. Тому пріоритетним чин- 
ником формування їх конкурентоспроможності є ефективне прийняття фінансових рішень у фінансовому менеджменті, тобто ефективне прийняття фінансових рішень, розподіл та перерозподіл фінансових ресурсів, рух коштів корпорації, що має грунтуватися на всебічному контролі, що забезпечує цілеспрямований характер розподілу та певну норму прибутку на вкАадений капітал.

Методи фінансового менеджменту та контролю, засновані на застарілих методах бухгалтерського обліку та аналізу, а також планового та факторного аналізу, недозволяють отримати достовірні результати. Сучасні умови диктують необхідність якісної зміни фінансового контролю як основи з метою забезпечення реалізації важелів механізму фінансового управління корпорації, у тому числі прогнозних показників та досягнення Стратегічних цілей та завдань розвитку корпорації. Внутрішній фінансовий контроль с важАивим елементом системи фінансового менеджменту Аля прийняття та реалізації ефективних управлінських рішень та має проникати на всі рівні управління, забезпечуючи високоякісні результати УПравлінської, діяльості. Таким чином, внутрішній корпоративний фінансовий контроль Спрямований на адаптацію виробничої та управлінської Систем корпорації до мінливого зовнішнього середовища, досягнення цільових показників фінансової,діяьності та стабільне фінансове становище корпорації на промислових ринках. Тому ефективна компанія повинна мати чітко налагоджене фінансове управління, що в Умовах жорсткої конкуренції є гарантією успішної діяльності будь-якого підприємСтва.

Наприкінці статті подано Узагальнені висновки 3 досліджуваної теми.

Key words: financial management, audit, electronic auditing, innovative auditing, the business environment, tax control, and new technology

Ключові слова: фінансовий менеджмент, аудит, електронний аудит, інновачійний аудит, бізнес-середовище, податковий контроль, передові технології.

\section{PROBLEM STATEMENT}

The rising engagement of industrial businesses in the country's economy, particularly in the development of the energy sector, has a multiplier effect on the development of financial control in Azerbaijan's national corporations under present economic conditions. Financial management aims to make it easier for firm leaders to implement financial policies they have devised and adopted by organizing financial and information resources to give them a realistic picture for an effective decision-making. The enhancement of commercial operations and the growth of efficiency in the development of industrial businesses allow them to occupy the most advantageous position in front of investors and creditors.

An "open" corporation ensures successful corporate financial management and sets circumstances for effective management of personnel, shareholders, and regulators.

\section{ANALYSIS OF RECENT RESEARCH AND PUBLICATIONS}

The topics of financial management and control were extensively discussed in the work of V. Novruzov "Audit in Azerbaijan: from formation to international standards," and "Audit" written by E.M. Lebedeva. The similar issues were also addressed in the works of Asadova A., Ildamanova A.S., and others.

\section{PURPOSE OF THE ARTICLE}

Analyze the specifics of the financial position at Azerbaijani firms in the modern context and make recommendations for further enhancing the process while keeping important duties in mind.

\section{PRESENTATION OF THE KEY MATERIAL}

Introduction

The organization of financial control, taking into account new quality criteria, is critical in order to improve the efficiency and transparency of the corporate environment in developed nations, including Azerbaijan, in order to solve national and global development concerns. Increasing business efficiency currently necessitates a comprehensive solution to problems caused by external and internal factors, such as changes in the macroeconomic situation, the impact of international financial and economic processes on the country's economy, increased competition in domestic and international markets, and the use of financial management mechanisms, all of which contribute to the formation of a new approach to business management. In this regard, it is vital to investigate the function of audit services, internal control, and other financial management systems, which are widely used throughout the world and have greatly strengthened their regulatory positions in all sectors of the economy.

Increasing business efficiency currently necessitates a comprehensive solution to problems caused by external and internal factors such as macroeconomic changes, the impact of international financial and economic processes on the country's economy, increased competition in domestic and international markets, and the use of financial management mechanisms, all of which contribute to a reduction in business efficiency. In this regard, it is vital to investigate the function of audit services, internal control, and other financial management systems, which are widely used throughout the world and have greatly streng thened their regulatory positions in all sectors of the economy.

\section{The importance of financial management} mechanisms in the modern context

It should be highlighted that the level of economic development and the construction of democratic institutions are both closely tied to increased openness. Strengthening budgetary controls, increasing tax system transparency, continuing to change tax culture, bolstering positive trends in the Accounts Chamber's activities, simplifying budget classification, and raising public awareness are all ways to improve the effectiveness of financial controls and reduce corruption risks.

Issues such as regular implementation of legal, administrative, and institutional procedures, financial discipline, proper money allocation, and increased economic efficiency are particularly significant in this regard. It is also critical to increase the engagement of independent auditors in checking the accuracy of the state budget and social protection funds' development and utilization. 
Non-governmental organizations and non-state structures play a critical role in organizing control over the state's financial resources. Azerbaijan already has this strategic route in place, and it has a promising future. Independent auditors, as well as local and multinational audit firms, operate in the country's audit sector.

At the same time, research into issues such as unfair competition in the audit services market and the preference for local audit organizations is crucial for the development of national audit organizations, in addition to supporting the grow th of the audit service as a whole [1, p. 23].

One of the main directions of governmental financial control is tax control, which oversees taxpayer accounts, taxation purposes, and tax legislation. According to experience, the normal operation of a country's tax system is based on effective tax control.

As a result, tax reform should concentrate on improving tax structure and enforcement. Simultaneously, tax supervision should be aimed not only at correcting defects in taxpayer behavior, but also at ensuring that laws and judgements are enforced.

Tax control differs from other types of control in that it allows only those acts that are authorized by law to be utilized, such as the application of measures of responsibility, which can only be used if it is approved by law.

Tax audits carried out in the tax control system utilizing modern information technology and accompanying applications set the foundation for more transparent operations and the prevention of corruption. As a result, recent tax and audit reforms promote new economic successes as well as the establishment and expansion of small and medium-sized firms.

Furthermore, risk management and analysis are critical for increasing the company's efficiency. Risk management is carried out by state bodies engaged in many sorts of operations, as well as the private sector, utilizing risk analysis and monitoring, loss reduction, and various insurance methods [2].

\section{Information technology in improving} the financial control system

According to the findings, broadening the use of current technologies in management, as well as speeding up the acquisition, integration, and dissemination of new information and technologies based on global experience is vital. Strengthening public control over government revenues and expenditures makes it easier to examine and debate government agencies' actions, boosts public trust in government entities, promotes accountability, and, as a result, increases transparency.

Furthermore, the use of governance mechanisms in the field of financial control, civil society participation in the development of programs and draft laws, public hearings, raising awareness of ethical issues and publicly disclosing them, and investigating complaints about ethical violations will create conditions for effective work and improve management efficiency. Strengthening regulator accountability, incorporating information technology into the control system or establishing electronic control, structuring financial control statistics, and improving the training systems are all key aspects of financial control. The ability of financial professionals to shield themselves from the detrimental impacts of the internal and external environment, as well as a high level of financial management, are required to achieve financial transparency for any business or economic institution [3, p.159-165; 4].

Audit and Electronic Audit Application Issues

At this level of economic development, audit is very important for developing the financial system of economic entities as a means of effective financial control. The audit service should assist businesses and entrepreneurs in applying worldwide financial standards to their operations, as well as mediate in financial risk management and the adoption of suitable risk regulations [5].

Research shows that in addition to the work done on the development of audit, there are a number of problems: - Non-compliance by businesses with the legislation's provisions in terms of maintaining the transparency of their financial statements;

- Unsatisfactory quality of audit services;

- Lack of awareness, advocacy and advocacy related issues to audit;

- Lack of trust of users of audit services;

- Inadequate assessment of the benefits of audit for the real sector, and others.

To close these gaps, developed-country experience must be used to improve the conditions for independent auditing, organize exams for independent audits to ensure high professionalism, align auditing limitations with international practice, implement electronic audit, and include provisions such as improved control by independent auditors and audit organizations. Using correct processes to integrate electronic audit into the tax system, as well as automated analysis of tax evasion threats, has a big impact on studying the peculiarities of each region and how electronic audit works in this field. Simultaneously, incorporating automated auditing into the tax system reduces the amount of time and human resources spent on audits while also improving their efficiency.

To summarize the significance of the electronic domain, the following points might be made:

- Utilize electronic audit to increases the ability of tax authorities to process electronic information provided by taxpayers;

- Develop the audit system in Azerbaijan using the most modern audit methods and technologies;

- Prevent from tax evasion and fraud without increasing the administrative burden and costs of tax audits;

- Create conditions for attracting taxpayers.

Innovation audit in the modern context

In this regard, innovative audit is now widely regarded as a critical component in determining the efficacy of creative processes in industrial enterprises.

The development of an innovative economy has long been proven to be one of the most important aspects in the effective construction of market relations and boosting the competitiveness of the national economy.

In our opinion, conducting innovation audits at enterprises and organizations is important when solving the following issues:

- Expands opportunities for employment of an innovative type;

- Forms a competitive environment in the country;

- Identifies current and future opportunities for innovation in the enterprise;

- Helps to remove barriers to innovation;

- Leads the explanation of new methods of innovative opportunities;

- Identifies innovative opportunities by assessing the technological potential of manufacturing enterprises.

The main feature of the new stage of development is the use of management that meets international standards.

Taking all of this into account, innovation audit plays a significant role in enhancing the business environment, including risk management in compliance with modern regulations and the development of an innovative economy.

Simultaneously, elements such as developing innovation auditing standards in accordance with the national development model, conducting information activities on innovation audit, and providing training in this area should be considered [6].

\section{Independent audit institute and professional ism}

Another issue is a lack of professional personnel, as well as the establishment of an independent audit institution's 
interaction with state financial control and its organization in accordance with international practice, including the development of uniform norms, standards, and rules of control for financial control bodies.

In this regard, taking into account the following topics will lay the groundwork for extending auditing and increasing the value of audit services:

- Building public trust and confidence in the audit;

- Increase the responsibility of auditors to ensure the transparency of financial statements;

- Ensure compliance with international auditing standards, international financial reporting standards and the Code of Ethics for Professional Accountants;

- Formation of a healthy competitive environment in the service market;

- Increasing the competitiveness of the national audit and accelerating the integration of the national audit market into the world market;

- strengthening the role of audit in ensuring maximum protection of the interests of various parties in corporate governance.

Taking these factors into account, establishing an audit service as part of a business or economic entity's activities can serve as a basis for minimizing and controlling risks in the economic and financial realms, hence increasing the control system's efficacy.

\section{CONCLUSION}

The role and importance of financial control is growing in Azerbaijan as a result of socioeconomic developments and the strengthening of budgetary and tax discipline.

In this regard, one of the key tasks of state policy is to establish a system of state financial control that meets modern criteria and improves its efficiency. Tax control is one of the most important aspects of state financial management. Tax control should focus not only on shortcomings in the activities of taxpayers, but also on the extent to which they comply with the law in order to ensure the full implementation of legislative acts and make the necessary changes.

Simultaneously, the development of modern innovative tax control technologies, such as electronic audit, improves the efficiency of tax audits. The importance of electronic audit is to prevent tax evasion and fraud, as well as to provide conditions for taxpayer disciplinary actions without adding to the administrative burden and costs of audits.

The audit should not be limited to the examination of the company's or organization's financial documents; it should also summarize the findings based on an analysis of the current situation, provide accurate financial forecasts for future growth, and make realistic proposals for the development and implementation of new models.

The auditor also provides legal advice, such as tax, management, audit representation in courts and tax authorities on tax and customs disputes, information technology, property valuation, business risk assessment, business plan development, and marketing advice on research, all of which contribute to the efficiency of the enterprise. The use of an innovation audit aids in the identification of current and future prospects for innovation in the organization, the removal of obstacles to innovation, the elucidation of new innovation approaches, and the assessment of technological potential. The construction of a partnership between an independent audit institution and public financial control is another issue related to the development of audit.

The implementation of risk-based control concepts in audit planning, as well as the strengthening of software in small and medium-sized audit firms, should be given special attention.

To improve the efficiency of the business environment, it is necessary to optimize administrative and economic methods, stimulate investment activity, develop comprehensive measures to increase transparency in non- oil industry management, stimulate the development of small businesses in the field of innovation, improve bank lending to small and medium-sized enterprises, and ensure their effective access to financial resources.

\section{References:}

1. Novruzov, V. (2012), "Audit in Azerbaijan: from formation to international standards]", Problemy primenenija mezhdunarodnoj finansovoj otchetnosti $i$ standartov audita v povyshenii prozrachnosti, Materialy III Evrazijskogo foruma buhgalterov i auditorov [Problems of the Application of International Financial Reporting and Auditing Standards in Increasing Transparency, Materials of the III of the Eurasian Forum of Accountants and Auditors]. Baku, Republic of Azerbaijan.

2. Musaev, A.F. (2004), Jekonomicheskie problemy nalogovoj politiki [Economic problems of tax policy], Nauka, Baku, Republic of Azerbaijan.

3. Ismayilov, M.E (2014), "Study of international experience in taxation of e-commerce", Tax Journal of Azerbaijan, vol. 6, pp. 159-165.

4. Asadov, A. (2012), "Role and methodological features of electronic audit in increasing transparency", Materialy III Evrazijskogo foruma buhgalterov i auditorov [Materials of the III of the Eurasian Forum of Accountants and Auditors], Baku, Republic of Azerbaijan.

5. Lebedeva, E.M. (2014), Audit [Audit], Akademija, Moscow, Russian Federation.

6. Ildemenov, A.S. (2012), Operacionnyj menedzhment [Operations management], Moscow, Russian Federation. Стаття надійлла до редакції 04.11.2021 p.

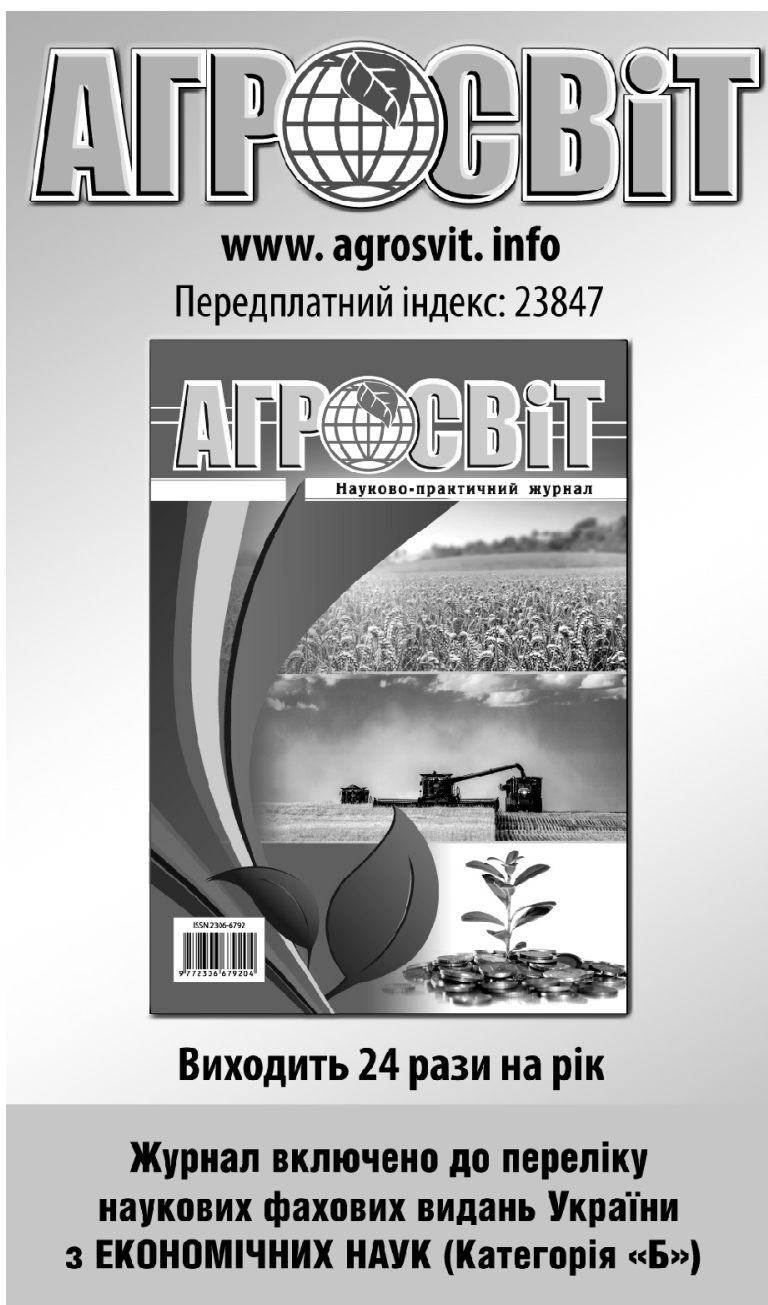

Спеціальності - 051, 071, 072, 073, 075, 076, 292 